\title{
Study and Practice On the Quality Eval- uation System of Practical Teaching in Colleges
}

\author{
Guojuan Zhang ${ }^{1}$ Guofang Zhang ${ }^{2}$ \\ ${ }^{1}$ Deputy chief of Teaching Affairs Office,Hebei college of Industry and Technolo- \\ gy,Shijiazhuang,China \\ ${ }^{2}$ Library,Hebei University of Engineering,Handan,China
}

\begin{abstract}
At the moment, there is a whole evaluation system on theoritical course instruction quality in every college. However, practical course doesn't have standard evaluation system. Based on above, triune pyramid stereochemical structure in practical teaching quality evaluation system has been developed through broadly consulting, and has been applied into teaching management. So, some probes as following in practical quality assessing.
\end{abstract}

Key words: practical teaching; quality evaluation; evaluation indicator

\section{Introduction}

It is important part for college teaching quality that its evaluation system guided college education orientation. In the long term, college education pays attention to theory and practice not as well as. So the graduates lacks practical competency. It is wanted college integrating practice with a whole practical teaching quality evaluation. This system can facilitate positive and initiative between student's study, and help to grasp teaching emphasis and practical teaching reform between tutors.

A survey is given to this system through national college practical teaching evaluation indicator and abroad, on the basis of conducting students, teachers and experts opinions, practical teaching evaluation indicator is established with objective and rational in practical teaching evaluation. It consists students, supervisors and experts evaluation. Among the evaluations, students and supervisors evaluation start from experience, field and internship courses. It exerts important role about this triune pyramid stereochemical structure practical teaching evaluation system in colleges.

\section{The Status Quo Of Practical Teach- ing Quality Evaluation Research}

In a long term, traditional higher education focuses on theory, belittles practice, leads graduates to lack practical and adaptable competence, all of these situations should be due to contemporary college teaching quality evaluation. At the moment, there is a whole evaluationsystem on theoritical course instruction quality in every college. However, practical course doesn't have standard evaluation system.

\section{Background For Practical Teaching Quality Evaluation System Devel- oping}

Higher education should set adopting objects according to society needs, meanwhile, it should stress to cultivate practi- 
cal ability of students. Colleges teaching quality evaluation system orients schools' education, it is a guarantee for appealing initiatives between teachers and students.

Successful quality education should advocate and promote method of field instruction, integrates basic knowledge and skill with diversified internship, experiment and studying on site. Enabling students to understand principles of productive process and knowledge for productive management. Therefore, on the basis of conducting students, teachers and experts opinions, practical teaching evaluation indicator is established with objective and rational in practical teaching evaluation.

\section{Structure For Practical Teaching Quality Evaluation System}

practical teaching quality evaluation system provides three levels including students, supervisors and experts evaluation. In this pyramid structure, radix number of students evaluation is big as well as its impacts as foundation bed of the pyramid; formative evaluation is supervisors evaluation as intermediate level; experts evaluation is to assess a whole practical teaching quality of a college. Students and supervisors evaluation start from experience, field and internship courses, it is triune pyramid stereochemical structure in practical teaching quality evaluation system.

\section{Indicators For Practical Teaching Quality Evaluation System}

The soft of "practical teaching quality evaluation system" devides into three modules which are students, supervisors and experts evaluation according to indicators for experiment course, field course and internship course evaluation. Each indicator has five types of scores which are $2,4,6,8$ and 10 points, multiplying its weights, then adding together, the results is appraisal report for a teacher. Formula is following:

$$
Z=\sum P i \bullet X i
$$

$\mathrm{Z}$ represents scores of one course, $P i$ represents indicator weights of No.i, $X i$ represents score of No.i.

\subsection{Teaching Quality Evaluation of Experimental Course}

Experimental course is defined to clarify some process or phenomenon or result as an aim. It could be adopted administrative mode of normative streamline, enabling students to promote their operation competence, enforcing their understand for basic knowledge and skill.

Table 1 Evaluation Indicators in Experimental Course

\begin{tabular}{|c|c|c|}
\hline $\begin{array}{l}\text { First Level } \\
\text { Indicator }\end{array}$ & Appraisal Contents & Weight \\
\hline $\begin{array}{l}\text { Attitude for } \\
\text { Teaching }\end{array}$ & $\begin{array}{l}\text { Instruments of Teacher for } \\
\text { Pre-Class }\end{array}$ & 0.03 \\
\hline $\begin{array}{l}\text { Attitude for } \\
\text { Teaching }\end{array}$ & $\begin{array}{l}\text { Management Ability of } \\
\text { Teacher for While-Class }\end{array}$ & 0.03 \\
\hline $\begin{array}{l}\text { Attitude for } \\
\text { Teaching }\end{array}$ & $\begin{array}{l}\text { Preparement of Experimental } \\
\text { Data for Pre-Class }\end{array}$ & 0.04 \\
\hline $\begin{array}{l}\text { Teaching } \\
\text { Contents }\end{array}$ & $\begin{array}{l}\text { Declaration for Cautions of } \\
\text { Experiment }\end{array}$ & 0.1 \\
\hline $\begin{array}{l}\text { Teaching } \\
\text { Contents }\end{array}$ & $\begin{array}{l}\text { Instruction for Process of } \\
\text { Experiment with Patience }\end{array}$ & 0.1 \\
\hline $\begin{array}{l}\text { Teaching } \\
\text { Method }\end{array}$ & $\begin{array}{l}\text { Time Arrangement Between } \\
\text { Demonstration and Operation }\end{array}$ & 0.1 \\
\hline $\begin{array}{l}\text { Teaching } \\
\text { Method }\end{array}$ & $\begin{array}{l}\text { Pay Attention to Adopt the } \\
\text { Ability of Working and Oper- } \\
\text { ating }\end{array}$ & 0.1 \\
\hline $\begin{array}{l}\text { Teaching } \\
\text { Method }\end{array}$ & $\begin{array}{l}\text { Answer the Questions with } \\
\text { Patience in the } \\
\text { Course of Experiment }\end{array}$ & 0.1 \\
\hline $\begin{array}{l}\text { Teaching } \\
\text { Performance }\end{array}$ & Impressive, & 0.4 \\
\hline
\end{tabular}




\subsection{Teaching Quality Evaluation of Field Course}

Field course is defined to simulate real workplace and productive process, is to adopt their ability of linking theory with practice, of working, of thinking, of operating and of innovating.

Table 2 Indicators in Field Course

\begin{tabular}{|c|c|c|}
\hline $\begin{array}{l}\text { First Level } \\
\text { Indicator }\end{array}$ & Appraisal Contents & Weight \\
\hline $\begin{array}{l}\text { Attitude for } \\
\text { Teaching }\end{array}$ & $\begin{array}{l}\text { Instruments of Teacher } \\
\text { for Pre-Class }\end{array}$ & 0.03 \\
\hline $\begin{array}{l}\text { Attitude for } \\
\text { Teaching }\end{array}$ & $\begin{array}{l}\text { Management Ability of } \\
\text { Teacher for While- } \\
\text { Class }\end{array}$ & 0.03 \\
\hline $\begin{array}{l}\text { Attitude for } \\
\text { Teaching }\end{array}$ & $\begin{array}{l}\text { Preparement of Exper- } \\
\text { imental Data for Pre- } \\
\text { Class }\end{array}$ & 0.04 \\
\hline $\begin{array}{l}\text { Teaching } \\
\text { Contents }\end{array}$ & $\begin{array}{l}\text { Declaration for Cau- } \\
\text { tions of Experiment }\end{array}$ & 0.1 \\
\hline $\begin{array}{l}\text { Teaching } \\
\text { Contents }\end{array}$ & $\begin{array}{l}\text { Instruction for Process } \\
\text { of Experiment with } \\
\text { Patience }\end{array}$ & 0.1 \\
\hline $\begin{array}{l}\text { Teaching } \\
\text { Method }\end{array}$ & $\begin{array}{l}\text { Time Arrangement Be- } \\
\text { tween Demonstration } \\
\text { and Operation }\end{array}$ & 0.1 \\
\hline $\begin{array}{l}\text { Teaching } \\
\text { Method }\end{array}$ & $\begin{array}{l}\text { Pay Attention to Adopt } \\
\text { the Ability of Working } \\
\text { and Operating }\end{array}$ & 0.1 \\
\hline $\begin{array}{l}\text { Teaching } \\
\text { Method }\end{array}$ & $\begin{array}{l}\text { Answer the Questions } \\
\text { with Patience in the } \\
\text { Course of Experiment }\end{array}$ & 0.1 \\
\hline $\begin{array}{l}\text { Teaching } \\
\text { Performance }\end{array}$ & Impressive, & 0.4 \\
\hline
\end{tabular}

\subsection{Teaching Quality Evaluation of In- ternship Course}

Internship course refers to take students to actual workplaces, let them work, is to improve their suitable skill and placement competiveness. At the same time, performance of the whole teaching management of the college is being checked.

\section{Conclusion}

Practical teaching quality is an important part of college teaching quality, is an important content of college educational reform. At present, each college has complete appraisal system for theoretical course and not as well as practical course. Based on above, triune pyramid stereochemical structure in practical teaching quality evaluation system has been developed, and has been applied into teaching management.

\section{References}

[1] Chen Hong. Construction and Application on College Practical Teaching Quality Evaluation Model. Laboratory Reseach and Probe, 2009, 28(6):159-161.

[2] Xu Yonggang. Study on Higher Vocational Education Practical Teaching Appraisal Standard and Performance. Education and Vocation, 2,2009:163164.

[3] Feng Xiao'an. Construction and Implement on Practical Teaching Evaluation Indicator System. China Electric Power Education, 2010,13:125-126.

[4] Li Chunhui. Reseach on College Practical Teaching Qulity Comprehensive Appraisal System. Experimental Technology and Management, 2009, 26(3):222-224.

[5] Zhang Weizhong. Research on Constructing Practical Teaching Quality Evaluation Indicators. Journal of Nanchang College of Engineering, 2008,27(2):62-64. 